\title{
COMPETENCIES REQUIRED FOR THE IMPLEMENTATION OF AN EFFICIENT SUPPLY CHAIN FROM THE PERSPECTIVES OF STUDENTS AND THE LABOUR MARKET
} A HATÉKONY ELLÁTÁSI LÁNC MEGVALÓSULÁSÁHOZ SZÜKSÉGES
KOMPETENCIÁK HALLGATÓI ÉS MUNKAERÖPIACI SZEMSZÖGBŐL

The supply chain, the system granting customer satisfaction, is an important field in our changing world. This field's profit-oriented companies seek employees with the competencies to achieve their goals. This research's aim was to raise awareness of those competencies that should be developed. The authors questioned 110 supply chain management (SCM) master's degree (MSc) students from Corvinus University of Budapest (CUB) and performed a significance test on their answers. They were asked to assess 17 competency groups and state the extent to which - on a scale from 0 to 100 - supply chain managers need them. One of the most interesting results was the assessment of presentation skills, which indicated differences between the competencies that companies expected and those that students believed were required. This study not only lays the groundwork for further research but also emphasizes the relevance of those competencies to be developed and the rethinking of training outcome requirements.

Keywords: supply chain management, logistics, master's degree (MSc), competency, labour market

Gyorsan változó világunkban kiemelkedően fontos terület az ellátási lánc, mint a vevői elvárások kielégítéséhez hozzájáruló, vagy azt biztosító rendszer. Az ellátási lánc területen tevékenykedő vállalat céljai eléréséhez megfelelő képességekkel, készségekkel, attitűdökkel és tudással, vagyis kompetenciákkal rendelkező munkavállalókat keres. A kutatás célja ebből következően az oktatás során fejlesztendő kompetenciák tudatosítása volt. A szerzők megkérdezték a BCE ellátásilánc-menedzsment (ELM) 110 mesterszakos (MSc) hallgatóját, majd válaszaikon szignifikanciavizsgálatot végeztek. A kérdőívben 17 kompetenciacsoportról kellett eldönteni, hogy egy logisztikai, beszerzési, termelési, raktározási, vagy disztribúcióért felelős vezetőnek melyikre milyen mértékben - egy 0-100-ig terjedő skálán értékelve - van szüksége. Az egyik legérdekesebb eredmény a prezentációs készség megítélésben mutatkozott, mely eredmény az elvárt és elvártnak hitt kompetenciák közötti eltérésre mutatott rá. Ezek az eltérések nemcsak további kutatásokat alapoznak meg, hanem az oktatásban fejleszthető, illetve fejlesztendő kompetenciák relevanciáját és talán a képzési kimeneti követelmények újragondolását is előtérbe helyezik az ellátásilánc-menedzsment területén.

Kulcsszavak: ellátási lánc, logisztika, mesterképzés (MSc), kompetencia, munkaerőpiac

\section{Funding/Finanszírozás:}

The present publication is the outcome of the project „From Talent to Young Researcher project aimed at activities supporting the research career model in higher education", identifier EFOP-3.6.3-VEKOP-16-2017-00007 co-supported by the European Union, Hungary and the European Social Fund.

Jelen publikáció az Európai Unió, Magyarország és az Európai Szociális Alap társfinanszírozása által biztosított forrásból az EFOP-3.6.3-VEKOP-16-2017-00007 azonosítószámú „Tehetségből fiatal kutató - A kutatói életpályát támogató tevékenységek a felsőoktatásban" című projekt keretében jött létre.

\section{Author/Szerző:}

Adrienn Munkácsi, assistant lecturer, Corvinus University of Budapest, (munkacsi.adrienn@uni-corvinus.hu)

This article was received: 05. 02. 2021, revised: 14. 03. 2021, accepted: 08. 04. 2021.

A cikk beérkezett: 2021. 02. 05-én, javítva: 2021. 03. 14-én, elfogadva: 2021. 04. 08-án. 
$\mathrm{S}^{\mathrm{s}}$ atistics show that, in 2020, there were labour shortages in countless fields and sectors (KSH, 2020a), which supply chain managers (transport and warehousing) also have to face. In the third quarter of 2020, in the transport and warehousing sector, there were 3740 vacancies (rate of vacancies: 1.7\%) (KSH, 2020b), which suggests that the most restricting factor for efficiency is not the unemployment rate but the lack of human resources, for which there are numerous potential reasons (Munkácsi, 2019). In a supply chain (transport and warehousing), one of the possible reasons could be the difference between the competencies expected and those developed in the educational system, which indicates a lack of necessary competencies of graduating 'professionals'. Therefore, besides professional knowledge, emphasis should be placed on the development of the abilities and skills that potential employees need to succeed. Most of these are so-called soft skills, for example a complex and critical mindset and advanced communication and collaboration skills (Mihalkovné Szakács, 2014). These are abilities that still cannot be replaced by machines and that, with sufficient care, can be well developed during training.

Our research was based on previously specified competency criteria (e.g. the system approach, decision-making ability, and stress tolerance) determined by national (Patóné, 2006) and international (Derwik \& Hellström, 2017; Derwik, Hellström, \& Karlsson, 2016; Flöthmann \& Hoberg, 2017; Gibson, Gibson, \& Rutner, 1998; Keller, 1999; Myers, Griffith, Daugherty, \& Lusch, 2004; Thai, Cahoon, \& Tran, 2011; Van Hoek, 2001; Murphy, \& Poist, 1991) research on some outstanding tasks in the supply chain, with the aim of helping companies to achieve and maintain competitiveness and success. The goal of the present research was to define and compare the - possible - differences between the competencies required and those that the students believed to be required in the supply chain. Therefore, we assessed students' awareness of the expected competencies, as a result of which we can assist in defining the realistic expectations of the labour market. We consider this to be essential because, according to our experience, if students have realistic ideas and expectations concerning their specialization, they can identify more easily with the goals of the training (the training of marketable employees). If the goals and the methods applied to achieve these goals are known, students will be willing to invest more energy and will be more cooperative and more likely to follow the rules during training. These attributes are among the required competencies, and making students recall and apply them can be helpful for their work. Furthermore, they will understand the importance of the applied methods, which might increase their satisfaction. They will be more content with the training and their own performance as members of the workforce, which will most likely also increase the satisfaction of their employers. Thus, our research results can be important for newly graduated students aiming to work in the supply chain, for professors in training, and for potential employers since the expectations defined by the students might influence the processes of training and employment too.
We identify the market expectations using the results of the above-mentioned international research and the European Skills, Competences, Qualifications, and Occupations (ESCO) specifications. ESCO is an important tool supporting the Europe 2020 strategy and the new European skills development project. ESCO's classification determines and categorizes the skills, competencies, qualifications, and professions related to the EU labour market, education, and training. This classification system was developed by the European Commission's Directorate-General for Employment, Social Affairs, and Inclusion with the cooperation of stakeholders and the European Centre for the Development of Vocational Training (Cedefop) (ESCO, 2020a,b). The DeSeCo project - to be mentioned later - is also connected to this. Although, according to our assumptions, which are described later in our hypotheses, students have a realistic picture of the competencies required in each field, most of the time - except for trainees in dual education - they meet the labour market's expectations only after obtaining their degree. Thus, the present research's purpose is to help with students' preparation by developing training that satisfies the real expectations. In the implementation, we relied on our preceding research results (a student survey) and the results of international research.

There were discrepancies between the competencies developed in training and those expected in the workplace (KSH, 2020b) even before starting the research, which also supports our previous view that, besides transmitting knowledge, education, and training, institutions have to emphasize the development of the required competencies based on assessing and continuously following the market demands, which also require flexibility on the part of the institutions. According to Lutz and Birou (2013), for an institution to enter the market with useful training and successful professionals, closer cooperation between industry and education is essential.

Henceforth, to ensure accordance between stakeholders, after defining the concept of 'competency', we discuss the expectations of the supply chain's sub-systems based on the previously mentioned research (Derwik \& Hellström, 2017; Derwik et al., 2016; ESCO, 2020; Flöthmann \& Hoberg, 2017; Gibson et al., 1998; Keller, 1999; Myers et al., 2004; Thai et al., 2011). Then, we introduce the methodology and results of the research. We examine the students' answers first by field and then by analysing them and comparing them with each other to ascertain whether there is a significant difference between the competency expectations in each field and whether there is a difference between the competencies expected by employers and those believed to be expected by students. We close with conclusions and suggestions.

\section{Literature review}

In this section, we provide an overview of, define, and then frame the most important term that we examine and use: competency. This is essential because this concept's boundaries are blurred or mixed with other expressions 
(ability, skill, attitude, and knowledge), which might create barriers to interpretation. We sought to eliminate this possibility by clarifying the meaning of the concepts.

\section{Ability and skill}

We will see later that, in clarifying the concept of competency, the concepts of ability and skill will be decisive. Ability and skill are often used as synonyms, despite the fact that several definitions seek to clarify the difference. To show the distinction, we present short descriptions. 'If the activity does not require the direct use of conscious- ness, we perform the activity basically automatically, we talk about skill, but when solving a complex task we need the combination of a wide range of knowledge and skills, we talk about ability' (Falus, 2010, p. 7). Furthermore, Falus et al. (2009) highlighted that 'skill' mostly appears as an ability, despite the fact that it contains three well-separated psychic formations in Hungarian (p. 9):

1. practical skills for the automatic execution of simple operations,

2. skills for partially automated execution of more complex operations, and

\section{Definitions of competency presented by authors}

\begin{tabular}{|c|c|}
\hline Source & Competency \\
\hline $\begin{array}{l}\text { ESCO, } \\
\text { (EQF) }(2020, \\
\text { p. 19) }\end{array}$ & $\begin{array}{l}\text { 'Competence: The proven ability to use knowledge, skills and personal, social and/or methodological } \\
\text { abilities, in work or study situations, and in professional and personal development' }\end{array}$ \\
\hline $\begin{array}{l}\text { Council of } \\
\text { the EU (2018, } \\
\text { p. 7) }\end{array}$ & $\begin{array}{l}\text { 'one's ability to combine Knowledge, Skills and Attitude [KSA's] to show expected behaviour when } \\
\text { performing a professional task' }\end{array}$ \\
\hline $\begin{array}{l}\text { Cedefop } \\
\text { (European } \\
\text { Centre for the } \\
\text { Development of } \\
\text { Vocational } \\
\text { Training) }(2014, \\
\text { pp. } 47-48)\end{array}$ & $\begin{array}{l}\text { 'competence ability to apply learning outcomes adequately in a defined context (education, work, } \\
\text { personal or professional development) or ability to use knowledge, skills and personal, social and/or } \\
\text { methodological abilities, in work or study situations and in professional and personal development. } \\
\text { Competence is not limited to cognitive elements (involving the use of theory, concepts or tacit } \\
\text { knowledge); it also encompasses functional aspects (including technical skills) as well as interpersonal } \\
\text { attributes (e.g. social or organisational skills) and ethical values.' }\end{array}$ \\
\hline $\begin{array}{l}\text { Male, Bush } \\
\text { and Chapman } \\
(2011, \text { p. 154) }\end{array}$ & Competency: 'actions, assumed to be manifestations of knowledge, skills, attitudes and dispositions.' \\
\hline \begin{tabular}{|l} 
DeSeCo \\
(2004. p. 321)
\end{tabular} & $\begin{array}{l}\text { 'competence designates a complex action system encompassing knowledge, cognitive skills, attitudes and } \\
\text { other non-cognitive components" "Each competence corresponds to a combination of interrelated } \\
\text { cognitive and practical skills, knowledge and personal qualities such as motivation, values and ethics, } \\
\text { attitudes and emotions. These components are mobilised together for effective action in a particular } \\
\text { context.' }\end{array}$ \\
\hline $\begin{array}{l}\text { Boyatzis } \\
(1982, \text { p. } 23 \\
2008, \text { p. } 6)\end{array}$ & $\begin{array}{l}\text { 1982, p. } 23: \text { 'A threshold competency is a person's generic knowledge, motive, trait, self-image, social } \\
\text { role, or skill which is essential to performing a job, but is not causally related to superior job } \\
\text { performance.' ' } 2008 \text { p. } 6 .: \text {,A competency is defined as a capability or ability.' }\end{array}$ \\
\hline $\begin{array}{l}\text { Patóné } \\
\text { (2006) in Pató } \\
\text { Gáborné Szúcs } \\
\text { Beáta et al. } \\
(2021)\end{array}$ & $\begin{array}{l}\text { 'The set of an individual's characteristics that - through the performance of work tasks - contributes to the } \\
\text { achievment of organizational goals.' }\end{array}$ \\
\hline \begin{tabular}{|lr|}
\multicolumn{2}{|l|}{ Baartman } \\
and De \\
Bruijn $\quad(2011$, \\
p. 126)
\end{tabular} & $\begin{array}{l}\text { competency: 'consisting of integrated pieces of knowledge, skills and attitudes', and it is assumed to be } \\
\text { essential for appropriate functioning on the job. }\end{array}$ \\
\hline $\begin{array}{l}\text { ESDC (2020) } \\
(\text { Employment } \\
\text { and Social } \\
\text { Development } \\
\text { Canada) }\end{array}$ & $\begin{array}{l}\text { 'Competencies: The combined utilization of personal abilities and attributes, skills and knowledge to } \\
\text { effectively perform a job, role, function, task, or duty.' Source: Adapted from the Intermational Society for Performance } \\
\text { Improvement, and the Organization for Economic Co-operation and Development }\end{array}$ \\
\hline $\begin{array}{l}\text { Sauber, } \\
\text { McSurely } \\
\text { and Rao } \\
\text { Tummala } \\
(2008, \text { p. 375) }\end{array}$ & $\begin{array}{l}\text { 'A competency is a statement of learning outcomes based on awareness, a body of knowledge, or a skill. } \\
\text { When students exhibit a competency, they demonstrate a specific knowledge or an ability to do certain } \\
\text { things. That demonstration illustrates the outcomes of a learning process.' }\end{array}$ \\
\hline $\begin{array}{l}\text { Athey and } \\
\text { Orth }(1999, \mathrm{p} . \\
216)\end{array}$ & $\begin{array}{l}\text { competency is a set of observable performance dimensions, including individual knowledge, skills, } \\
\text { attitudes, and behaviors, as well as collective team, process, and organizational capabilities, that are } \\
\text { linked to high performance, and provide the organization with sustainable competitive advantage.' }\end{array}$ \\
\hline $\begin{array}{l}\text { Spencer and } \\
\text { Spencer } \\
(1993, \text { p. 4) }\end{array}$ & $\begin{array}{l}\text { competencies: 'motives, traits, self-concepts, attitudes or values, content knowledge, or cognitive or } \\
\text { behavioral skills - any individual characteristic that can be measured or counted reliably and that can be } \\
\text { shown to differentiate significantly between superior and average performers, or between effective and } \\
\text { ineffective performers.' }\end{array}$ \\
\hline
\end{tabular}


3. the ability to perform a more comprehensive activity, the ability.

The DeSeCo (Definition and Selection of Competencies) project - launched by the OECD in 1997 - also drew attention to the content difference between 'competence' and 'skill': 'in the DeSeCo project, the terms "competence" and "skill" are not used as synonyms. ... Skill is used to designate an ability to perform motor and/or cognitive acts' (Rychen, 2004, p. 321). The DeSeCo project is embedded into the OECD's long-term Education Indicators Project (INES), which aims to provide measures for the functioning, development, and impact of education and to complement international empirical studies, such as the Programme for International Student Assessment (PISA) (Rychen, 2004). ESCO's description of skills is 'The ability to apply knowledge and use know-how to complete tasks and solve problems. Skills are described as cognitive (involving the use of logical, intuitive and creative thinking) or practical (involving manual dexterity and the use of methods, materials, tools and instruments)' (ESCO, 2019 , p. 19). It is also important to mention the interpretation of 'skill' of Employment and Social Development Canada (ESDC) (n.d.): 'Developed capacities that an individual must have to be effective in a job, role, function, task, or duty' (ESDC: Adapted from the U.S. O*Net definition of skills). Skills are, for instance, communication skills and the ability to walk, talk, swim, drive a car, read, write, and so on. In the following, we clarify the concept of competency. we prepared some tables with a summary of the relevant definitions of competency from the international literature. To form a final position, we tried to find out as widely as possible and to present here the definitions that can be normative for education, for performing well in the world of work, and for the training of future generations. Among the concepts are the definitions by Boyatzis $(1982,2008)$ and Spencer and Spencer (1993), which are the most cited definitions in the field of management, both accepted and applied by organizations supporting competency-based education (EQF and Cedefop) and the spread of employment (ESCO, EU, DeSeCo, and ESDC) (Table 1).

Male, Bush, and Chapman (2001) examined the general competencies expected of Australian engineers, the normative concept being that of Cedefop (2014). Baartman and De Bruijn (2011), in their research, focused on complex work tasks. Sauber et al. (2008) reported on the competency model developed in the field of supply chain management. Athey and Orth (1999) examined the future competency methods. To obtain an overview of these approaches, explore the existing parallels, and help choose the acceptable normative concept more easily, we prepared Table 2. It shows the presence or absence of the elements (knowledge; skills, abilities, and attributes; attitude and others - KSA) that appear most often in the definition of competencies, broken down by the authors and organizations that are important for our research.

When examining the content elements of the competencies, the presence of the concepts of cognitive knowledge, knowledge, and ability can be observed in all classes. The

\section{Appearance of competency elements by authors}

Table 2

\begin{tabular}{|c|c|c|c|c|c|c|c|c|c|c|c|}
\hline $\begin{array}{c}\text { Authors/ } \\
\text { competency items }\end{array}$ & \begin{tabular}{|c} 
ESCO/ \\
EQF \\
$(\mathbf{2 0 2 0 )}$
\end{tabular} & 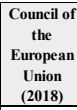 & $\begin{array}{l}\text { Cedefop } \\
\text { (2014) }\end{array}$ & $\begin{array}{c}\text { Male et al. } \\
\text { (2011) }\end{array}$ & $\begin{array}{l}\text { DeSeCo } \\
\text { (2004) }\end{array}$ & \begin{tabular}{|c|} 
Boyatzis \\
$(1982$, \\
$2008)$
\end{tabular} & $\begin{array}{c}\text { Baartman } \\
\text { and De } \\
\text { Bruijn } \\
(\mathbf{2 0 1 1}) \\
\end{array}$ & $\begin{array}{l}\text { ESDC } \\
(2020)\end{array}$ & $\begin{array}{l}\text { Sauber et } \\
\text { al. (2008) }\end{array}$ & $\begin{array}{c}\text { Athey and Orth } \\
\text { (1999) }\end{array}$ & $\begin{array}{l}\text { Spencer and } \\
\text { Spencer } \\
(1993)\end{array}$ \\
\hline knowledge & $\mathrm{x}$ & $\mathrm{x}$ & $\mathrm{x}$ & $\mathrm{x}$ & $\mathrm{x}$ & $\mathrm{x}$ & $\mathrm{x}$ & $\mathrm{x}$ & $\mathrm{x}$ & $\mathrm{x}$ & $\mathrm{x}$ \\
\hline $\begin{array}{l}\text { skills, abilities, and } \\
\text { attributes }\end{array}$ & $\mathrm{x}$ & $\mathrm{x}$ & $\mathrm{x}$ & $\mathrm{x}$ & $\mathrm{x}$ & $\mathrm{x}$ & $\mathrm{x}$ & $\mathrm{x}$ & $\mathrm{x}$ & $\mathrm{x}$ & $\mathrm{x}$ \\
\hline attitude & & $\mathrm{x}$ & $\mathrm{x}$ & $\mathrm{x}$ & $\mathrm{x}$ & & $\mathrm{x}$ & & & $\mathrm{x}$ & $\mathrm{x}$ \\
\hline others & \begin{tabular}{|c|} 
social \\
and/or \\
methodo- \\
logical \\
abilities
\end{tabular} & & \begin{tabular}{|l|} 
functional \\
aspects, \\
interper \\
sonal \\
attributes, \\
ethical \\
values
\end{tabular} & dispositions & $\begin{array}{c}\text { non-cognitive } \\
\text { components }\end{array}$ & $\begin{array}{c}\text { motive, trait, } \\
\text { self-image, } \\
\text { social role, } \\
\text { capability }\end{array}$ & & & awareness & $\begin{array}{l}\text { behaviours, } \\
\text { collective team, } \\
\text { process, } \\
\text { organizational } \\
\text { capabilities }\end{array}$ & $\begin{array}{l}\text { motives, traits, } \\
\text { self-concepts, } \\
\text { values, any } \\
\text { individual } \\
\text { characteristic }\end{array}$ \\
\hline
\end{tabular}

Source: own compilation

\section{Competency}

Regarding the concept of competency, we used the definition applied by ESCO and the European Qualification Framework for Lifelong Learning (EQF), in which competence is defined as 'The proven ability to use knowledge, skills and personal, social and/or methodological abilities, in work or study situations, and in professional and personal development' (ESCO, 2019, p. 19), which suggests that a person facing new situations and unexpected challenges can use his knowledge and skills in a self-directed manner (ESCO, 2020). To accept or reject this approach, 'attitude' line contains an ' $x$ ' only if it has been displayed in the definition by the authors themselves. In our research, we have often experienced a situation in which, although the term attitude itself did not appear in the definition, its content elements, for example behaviour, conduct, habit, or action, did. In our case, ESCO, Boyatzis, Sauber et al., and the ESDC are among these authors. Thus, it can be said that the theoretical background presented supports our commitment to the approach applied by ESCO and the Council of the European Union (2018). Henceforth, we adopt the following definition of competency: 
Competency: The proven ability to use knowledge, skills, and personal, social, and/or methodological abilities in work or study situations and in professional and personal development. It is one's ability to combine knowledge, skills, and attitude (KSA) to show the expected behaviour when performing a professional task.

In the following, we present a review from the employer and student perspectives and then compare results with the expected competencies of the supply chain. We determined the employers' expectations based on research found in the literature (Derwik et al., 2016; ESCO, 2020; Flöthmann \& Hoberg, 2017; Hoberg, Alicke, Flöthmann, \& Lundin, 2014; Keller, 1999; Munkácsi \& Demeter, 2019; Patóné, 2006; Thai et al., 2011), while the students' assessments were based on our own research.

\section{Expected competencies in the supply chain fields}

In the last three decades, there has been a continuous transformation in almost all fields of the supply chain, which has greatly influenced the expectations of and competency criteria for employees. According to Thai et al. (2011), nowadays, a successful logistics manager must have not only expertise but also business, logistics, and management skills.

This is supported by the research by Derwik and Hellström (2017) and Derwik et al. (2016), which explored managers' competencies in the logistics and supply chain field. As their final conclusion, they identified five major competency groups. Below, in the parentheses, the con- tents of each competence group and then the extent of their use during the daily activities and decision making of managers can be seen:

1. business managerial competence (dynamic awareness, business and stakeholder management) (observations $30-40 \%$ ),

2. generic competence (communication and cognitive abilities) (20-30\%),

3 . behavioural competence (intrapersonal and interpersonal) (15-30\%),

4. functional competence (technology and administrative routines) (5-20\%),

5. supply chain management expertise (supply chain management areas of expertise and applied analyses) $(0-5 \%)$.

Their results are consistent with our previous statement that, in education today, the development of soft skills is indispensable. Although professional knowledge is important in managers' everyday practice, without these skills and abilities, no one is capable of becoming a successful logistics manager. Flöthmann and Hoberg (2017) identified further abilities for complex daily tasks, such as a complex perspective and mindset, proficiency in different business fields, such as strategic decision making, communication, and management, intercultural skills, and analytic and informatic skills. According to Hoberg et al. (2014), those who work as managers in any field of logistics nowadays can be called 'decathletes'. Kovács and Pató (2014) stated that the required general competencies for transporters in supply chains are the following: make well-informed de-

Table 3.

Task definitions and connection to our own research

\begin{tabular}{|c|c|c|}
\hline Positions & ESCO definition by highlighting competencies & Competencies appearing in ESCO from our research \\
\hline $\begin{array}{l}\text { Logistics } \\
\text { and } \\
\text { distribution } \\
\text { managers }\end{array}$ & $\begin{array}{l}\text { "Logistics and distribution managers take decisions on logistic services, operations and } \\
\text { provisions. They take internal and external variables into consideration for effective and } \\
\text { successful organisational logistic services. They give appropriate support to all the activities } \\
\text { of the supply chain from the beginning to the end. These professionals organi se the storage and } \\
\text { distribution of goods and ensure that the right products are delivered to the right location on } \\
\text { time and at a good cost." }\end{array}$ & $\begin{array}{l}\text { complex mindset-system approach, collaboration skill, } \\
\text { communication skill, management ability, ability to } \\
\text { organize, work in a team, decision-making ability, } \\
\text { business approach, stress tolerance, ability to control and } \\
\text { evaluate, consistency, ability to follow the rules }\end{array}$ \\
\hline $\begin{array}{l}\text { Purchasing } \\
\text { managers }\end{array}$ & $\begin{array}{l}\text { "Purchasing managers are in charge of buying goods, equipment and services for their } \\
\text { company, and try to ensure the most competitive prices. They are also responsible for } \\
\text { negoti ating contracts, reviewing the quality of products and analyzi ng suppliers, and the use } \\
\text { and resale of goods and services." }\end{array}$ & $\begin{array}{l}\text { negotiation skills, complex mindset-system approach, } \\
\text { communication skill, organizational skills, management } \\
\text { ability, decision-making ability, business approach, } \\
\text { customer focus, ability to follow the rules }\end{array}$ \\
\hline $\begin{array}{l}\text { Industrial } \\
\text { production } \\
\text { managers }\end{array}$ & $\begin{array}{l}\text { "Industrial production managers oversee the operations and the resources needed in industrial } \\
\text { plants and manufacturing sites for a smooth running of the operations. They prepare the } \\
\text { production schedule by combining the requirements of clients with the resources of the } \\
\text { production plant. They organise the journey of incoming raw materials or semi finished } \\
\text { products in the plant until a final product is delivered by coordinating inventories, warehouses, } \\
\text { distribution, and support activities. }\end{array}$ & $\begin{array}{l}\text { complex mindset-system approach, collaboration skill, } \\
\text { ability to organize, customer focus, decision-making ability, } \\
\text { business approach, management ability, ability to control } \\
\text { and evaluate, ability to follow the rules }\end{array}$ \\
\hline $\begin{array}{l}\text { Warehouse } \\
\text { managers }\end{array}$ & $\begin{array}{l}\text { "Warehouse managers assume the responsibility for storage facilities. They manage the } \\
\text { operations and the staff within." }\end{array}$ & $\begin{array}{l}\text { complex mindset-system approach, collaboration skill, } \\
\text { communication skill, management ability, ability to } \\
\text { organize, work in a team, decision-making ability, ability } \\
\text { to control and evaluate, consistency, business approach, } \\
\text { ability to follow the rules, presentation skills, customer } \\
\text { focus }\end{array}$ \\
\hline $\begin{array}{l}\text { Distribution } \\
\text { managers }\end{array}$ & "Distribution managers plan the distribution of goods to various points of sales." & $\begin{array}{l}\text { complex mindset-system approach, collaboration skill, } \\
\text { communication skill, management ability, ability to } \\
\text { organize, work in a team, decision-making ability, } \\
\text { business approach, ability to control and evaluate, } \\
\text { consistency, ability to follow the rules }\end{array}$ \\
\hline
\end{tabular}


cisions swiftly, organize their own work and the work of others in an efficient way, communicate effectively with customers and other departments, coordinate work with the rest of the team and other departments, and act as an 'entrepreneur' when conceiving new business plans and networking outside the company. Pató, Kovács, and Pató (2006) listed the following necessary competencies: reliability, fairness, cultivated appearance, firmness, independence, communication skills, problem-solving ability, elaborateness, and result orientation.

Next we turn to the competency expectations for purchasing, production, warehousing, and distribution as the supply chain's fields or sub-systems. First, it is necessary to clarify the basic concepts in the fields and the tasks of the managers so that each reader understands the same contents of the given concepts. In our research, we defined the tasks following the ESCO definitions. The purchasing, production, warehousing, and distribution processes are parts of the so-called logistics system. 'It is the system of material flows and stocks, as well as the information and management structure connected to them' (Chikán, 2017). Purchasing, production supply, and distribution/sales are the three main phases/fields of the logistics process, which can be interpreted separately as the customer service cycle (Chikán, 2017; Demeter, Gelei, Jenei, \& Nagy, 2009). The warehousing tasks come into focus when there is stock accumulation because something hinders (breaking point) the process of the flow. This can also happen between the sections of purchasing and production or between production and distribution. ESCO (2020a) provided precise definitions of managers' tasks in the fields, from which we summarize the competencies appearing in our research in Table 3.

ESCO provides numerous alternatives for naming a position, for which - when looking any of them up - the same content appears. In the case of logistics manager, the default setting on ESCO's website is logistics and distribution manager, but the alternatives include logistics manager, which we use. For each position, ESCO divides the expectations in the given field into four levels. These levels are always based on essential skills and competences, then the essential knowledge follows, later the optional skills and competences, and last the optional knowledge. In our research, we focused (Annex 4) on the levels of essential skills and competences and optional skills and competences, which we used to compare the previous national and international research and the competencies that we examined. Reviewing Annex 4, three findings can be made: 1) it explains the competencies that are specifically expected in more detail than any research before, 2) all of these can be classified into our examined categories, and 3) the same type of task can be found with different wordings. The fact that the ESCO competencies can be classified into our categories allowed us to treat the competencies of our research as category groups. After defining the concepts and reviewing the important literature, we first present the methodology applied in our research and then the students' assessments of the competencies expected in the supply chain, which we also compare with the ESCO database.

\section{Methodology, data collection, and data analysis}

One of the aims of our research is to raise awareness among students participating in higher education (MSc) in the fields of supply chain management of the competencies that are required and that they should develop for successful employment by comparing students' opinion with national and international research results. It is likely that students - before applying to the supply chain management specialization - are familiar with the specifics and the criteria of employment and have a realistic picture of the expected competencies. Therefore, we set up two hypotheses:

H1: Students know that the most important labour market expectations of a logistics manager are a systems approach and management ability, which stand out significantly even compared with the assessments of the other managerial positions.

H2: Students know that the most important labour market expectations of a purchasing manager are negotiation and communication skills, which stand out significantly even compared with the evaluation of other managerial positions.

We note that, in our competency questionnaire, based on the research by Keller (1999) and Patóné (2006), the 23 competencies of the EU divided into three groups (managing, work, and key), defined in 2006, can also be identified (Annex 3). For the inquiry, we used an online questionnaire, which was shared twice with students at CUB-SCM (2017-2020). The method used for conducting the survey was the same in both cases. With the help of the groups' professors or people with responsibility, a link to the questionnaire appeared on a platform that was visible to all the members of the group - Facebook or Microsoft Teams - with a short message about the purpose of the research, and it could be filled in by using either a computer or a mobile phone. In total, 110 questionnaires could be evaluated. The questionnaire consisted of 14 questions, which included some data about the respondent (age - given on an interval scale, gender, nature of training, and name - as an optional parameter) and, the important elements of the research, questions to be answered on an adjustable scale between $0 \%$ and $100 \%$, such as: 'According to your opinion, how essential are the listed competencies (17) for 1. a logistics manager, 2 . a purchasing manager, 3 . a distribution manager, 4. an industrial production manager, and 5. a warehouse manager'.

The other questions referred to the development of the listed competencies and the respondents' methodological awareness and assessment of their usefulness, the results which can be found in a previous publication (Munkácsi \& Demeter, 2019). The database established is presented in Table 4.

Since there was no significant difference between the two samples, based on either age or gender distribution - which the chi-square test also proved - we handled the answers as one sample. In the following, we present the assessment of the expected competencies from a student 
perspective following two approaches. We first compare our results with national (Patóné, 2006) and international (ESCO, 2020; Keller, 1999) research by field (logistics, purchasing, production, warehousing, and distribution) and then by competency. Figure 1 and Table 6, which already contain the data side by side and ranked, serve to help monitor the results. we handled this 'field' as the expected competencies of a logistics manager. The following graph (Figure 1), aligned with the summary table, shows the student assessment for each manager by competency. Due to small deviations and the easier perception of outliers, the scale starts at $55 \%$ on the $\mathrm{Y}$ axis. To help ensure traceability, a concrete value was indicated for the outliers.

Table 4.

Information about the database

\begin{tabular}{|c|c|c|c|c|c|c|c|}
\hline & & & \multicolumn{2}{|c|}{ Gender } & \multicolumn{3}{|c|}{ Age } \\
\hline & $\%$ & Person & Female & Male & $21-23$ & $24-26$ & $27-30$ \\
\hline I. Data collection & 49 & 54 & 40 & 14 & 10 & 44 & 0 \\
\hline II. Data collection & 51 & 56 & 35 & 21 & 28 & 26 & 2 \\
\hline Sum & 100 & 110 & $75(67.6 \%)$ & $35(32.4 \%)$ & $\begin{array}{l}38 \\
(34.6 \%)\end{array} \mid$ & $\begin{array}{l}70 \\
(65.38 \%)\end{array}$ & $\begin{array}{l}2 \\
(0.02 \%)\end{array}$ \\
\hline
\end{tabular}

Source: own compilation

\section{Labour market expectations by field}

The first field is the 'logistics manager competencies', regarding which we can remark that, in the enclosed Tables 1 and 2, containing the specific expectations, the competencies of the logistics manager appear as 'expected comprehensive competencies in the logistics field within the company', because the research by Keller (1999) referred to two positions: logistics senior executive and supply chain manager. In Patóné's (2006) research, we started with the assumption - since no specific position was named - that the comprehensive competencies in the company's logistics field are the abilities and properties that a logistics manager has, along with other characteristics, for example knowledge, experience, and skills (see the definitions of competency presented earlier). Therefore,

\section{Expected competencies of a logistics manager}

In this position, communication and presentation skills (Keller, 1999) are outstandingly important, of which presentation skills are the least important for students; only customer orientation received lower scores. This is very surprising because a manager must have not only appropriate communication skills but also presentation and lecturing skills to be able to achieve the goals. The next unexpected result is that the ability to follow rules, which is very important for a manager because of the need to set an example, has also been pushed into the background. The system approach also plays an important role for logistics managers as a specific competency - comprehensive vision - in Keller's research. Decision-making ability is also included among the most important competencies;

\section{Differences in the assessment of managers' competencies}

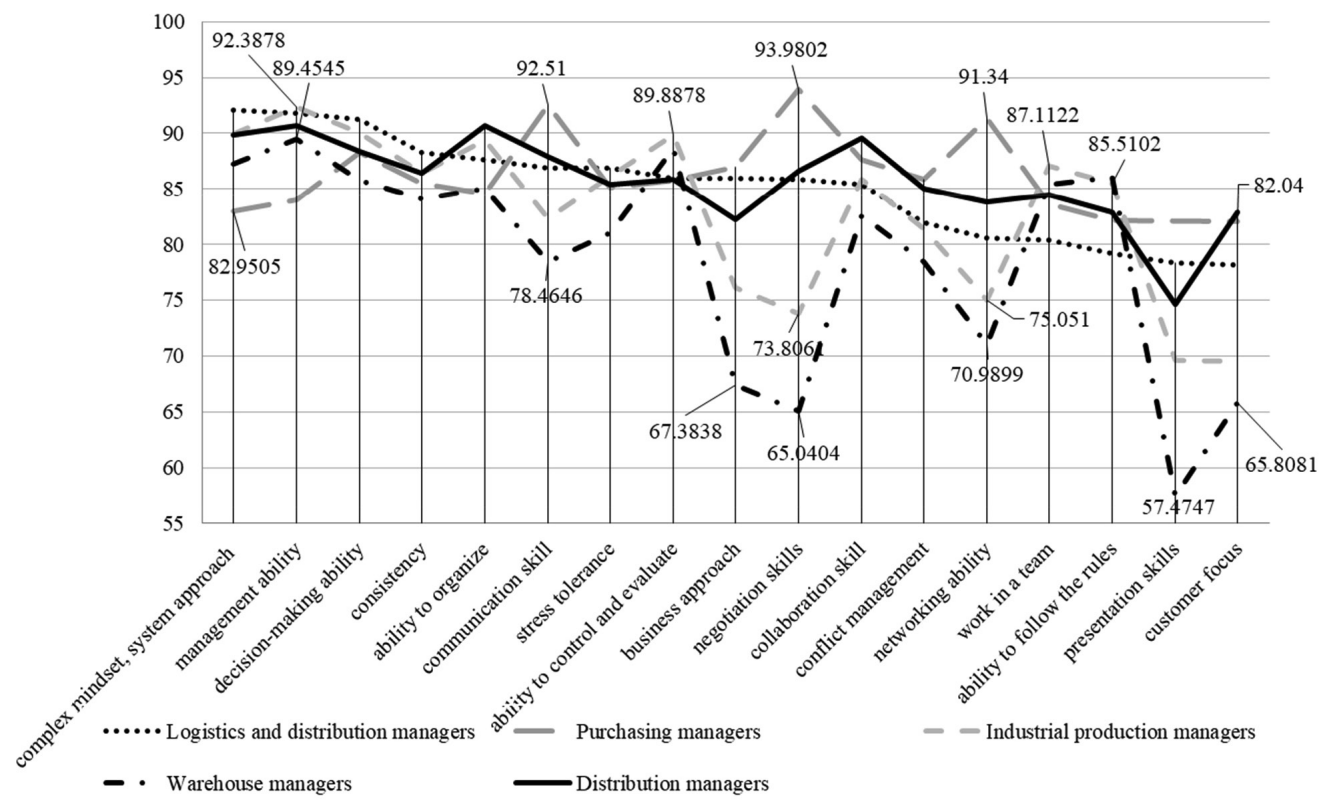


according to Keller, it is a specific expectation - effective decision-making ability - and, in the research by Patóné, decision-making ability is a general expectation. Students ranked organizational skills among the top five competencies, identified as specific in both studies. For Keller, it relates to the supply chain manager position. According to ESCO, logistics managers have much more specific $(S=21)$ (expected in the given field) competencies besides the 'generic' $(\mathrm{G}=13)$ managerial qualities (Annex 4) than in previous research.

\section{Expected competencies of a purchasing manager}

Based on Keller's research (1999), a purchasing manager's specific competencies are the use of communication techniques, conflict management, and the ability to conduct meetings. In Patóné's (2006) research, there are significantly more expectations among the specific competencies, such as negotiation skills, a comprehensive vision, the ability to control, a complex mindset, customer orientation, and so on. According to our research results, the most important requirement for a purchasing manager is negotiation skills, which are a specific competency both in Keller's (1999) - ability to conduct meetings and use of communication techniques - and in Patóné's (2006) research, as well as customer orientation, which surprisingly occupies the last place. In the second place is communication skills, then networking, decision-making, and collaboration skills, which are among the generic expectations in Patónés (2006) research. The ranking of these competencies - except for customer orientation - reflects students' good insights into the expectations of a purchasing manager. As for purchasing managers, it is surprising that communication skills do not appear as an expectation for ESCO, while, according to the students, it is the most important in this field. 'Handling customer relationships' and 'conducting meetings ...' suggest the expectation of communication skills. Despite occupying the midfield in the research, conflict management, consistency, and stress tolerance are completely absent. Teamwork (ranked 13th) and collaboration skills (ranked fifth) are also missing from ESCO's list, which rather features the characteristics necessary for effective decision making and a systems approach. Field-specific competencies determine the composition of the list the most (with a ratio of 25/15).

\section{Expected competencies of an industrial production manager}

Patóné (2006) did not specify competencies in this field, but in Keller's (1999) research, among the specific competencies, there are controlling and developmental skills, time management, and motivational skills. Placing management skills in first place is a remarkable idea for the future managers of logistics, since it concurs with the field-specific expectations, in the same way as control, evaluation, decision-making ability, and systems approach. Customer orientation is the least expected attribute, which is a realistic view in the case of a production manager. For ESCO, in the case of production managers, the system approach has an important role in the plan- ning, organizing, managing, and controlling of production processes. These tasks are mostly included. Interestingly, there are elements among the optional expectations that can be found in the case of logistics, warehouse, or purchasing managers, for example analysing supply chain strategies or assessing supplier risk. Another interesting fact is that, after the basic competencies, the following were mentioned as optional: define manufacturing quality criteria (define quality standards), develop manufacturing policies (create manufacturing guidelines), and schedule production (adjust the production schedule), highlighting the importance of these specific tasks.

\section{Expected competencies of a warehouse manager}

Keller's (1999) research identified two positions: warehouse inspector and warehouse manager. The most conspicuous difference is that, while the students ranked presentation skills last, Keller (1999) considered them as a specific competency. The managing, controlling, and evaluating skills, the systems approach, and the ability to follow rules are listed amongst the most important expectations, which is consistent with both previous studies. Patóné (2006), for instance, marked reviewing ability and consistency as specific competencies, which are compatible with the systems approach and the ability to follow rules. Furthermore, in this field, the greatest difference can be observed between the most important (management skills: $89.45 \%$ ) and the least important (presentation skills: $57.47 \%$ ) elements.

It is interesting that the students found decision-making ability to be much more important - in line with earlier research - than customer orientation, which was the third least important element. We emphasize these two competencies because, in modern warehouses, everything is controlled by machines and software, for example the placement of goods, the order of removal, the schedule, and the need for human resources. Almost all processes are strictly regulated, and managers do not really have to make independent decisions. In turn, if a warehouse is not customer oriented and goods are late or damaged, outstandingly high costs can arise (e.g. compensation costs, loss of customers, and loss of future orders). The warehouse manager's competencies were the most extensively explained by ESCO of all the managers examined. From the expectations listed here, we found two - 'maintain updated professional knowledge' and 'have computer literacy' - that do not fit into our list of 17 competencies. For the categorization of the other characteristics from our groups, decision-making ability, conflict management, stress tolerance, and negotiation skills did not emerge as labour market expectations for a warehouse manager. Most attributes could be categorized as 'ability to follow rules'. The additional 7-7-7 requirements could be arranged in the categories of management skills, system approach, and organizational skills, which, according to the students, are the most important for a warehouse manager. Our earlier statement that a warehouse manager no longer really needs independent decision-making ability but 
must have a customer-oriented approach seems to be proven here. In the case of ESCO, the costumer focus appears from various angles, for example performing services in a flexible manner, acting reliably, showing confidence, building business relationships, and improving business processes.
Expected competencies of a distribution manager In this field, management skills are the most important competency according to both students and international research, along with organizational skills, according to the students to the same extent. It is interesting that, while Keller considered these to be a leadership skill, in Patóné's

Significant differences in the assessment of managers' competencies

Table 6.

\begin{tabular}{|c|c|c|c|c|c|}
\hline BLACK-normal & \multicolumn{5}{|c|}{ not significant deviation $\mathrm{p}>0.05$} \\
\hline BLACK-BOLD & significant & deviation & $\mathrm{p}<0.05$ & & \\
\hline GREY & \multicolumn{5}{|c|}{ highest value within a given competency } \\
\hline$(\ldots)$ & \multicolumn{2}{|c|}{ e.g. in ESCO } & \multicolumn{3}{|c|}{ (1-5): 5 most important competency } \\
\hline $\begin{array}{l}\text { Managers/ } \\
\text { expected competencies }\end{array}$ & \begin{tabular}{|l|} 
Logistics and \\
distribution \\
managers \\
\end{tabular} & $\begin{array}{l}\text { Purchasing } \\
\text { managers }\end{array}$ & \begin{tabular}{|l|}
$\begin{array}{l}\text { Industrial } \\
\text { production } \\
\text { managers }\end{array}$ \\
\end{tabular} & $\begin{array}{l}\text { Warehouse } \\
\text { managers }\end{array}$ & $\begin{array}{l}\text { Distribution } \\
\text { managers }\end{array}$ \\
\hline $\begin{array}{l}\text { complex mindset, system } \\
\text { approach (develop..., } \\
\text { plan.., analyse) }\end{array}$ & 92.09 & 82.95 & (3) 89.9694 & (3) 87.2828 & (2) 89.899 \\
\hline management skills & 91.80 & 84.02 & (1) 92.3878 & (1) 89.4545 & (1) 90.7374 \\
\hline $\begin{array}{l}\text { independent decision- } \\
\text { making ability }\end{array}$ & 91.24 & (4) 88.28 & (2) 90.0204 & (5) 85.8182 & (4) 88.3636 \\
\hline consistency & 88.26 & 85.52 & 86.44 & 84.07 & 86.39 \\
\hline $\begin{array}{l}\text { organizational skills } \\
\text { (manage staff) }\end{array}$ & 87.61 & 84.57 & (5) 89.4082 & 85.06 & (1) 90.7374 \\
\hline $\begin{array}{l}\text { stress tolerance (handle } \\
\text { stressful situations, stress } \\
\text { management) }\end{array}$ & 86.88 & 85.17 & 86.17 & 81.03 & 85.44 \\
\hline communication skills & 86.88 & (2) 92.51 & 82.36 & 78.46 & (5) 87.9293 \\
\hline $\begin{array}{l}\text { ability to control } \\
\text { (monitor) and evaluate }\end{array}$ & 85.95 & 85.77 & (4) 89.8878 & (2) 88.6263 & 85.88 \\
\hline $\begin{array}{l}\text { business approach } \\
\text { (consider economic } \\
\text { criteria in decision } \\
\text { making) }\end{array}$ & 85.92 & 86.99 & 76.13 & 67.38 & 82.28 \\
\hline negotiation skills & 85.89 & (1) 93.9802 & 73.81 & 65.04 & 86.59 \\
\hline $\begin{array}{l}\text { collaboration skills } \\
\text { (liaise with colleagues) }\end{array}$ & 85.41 & (5) 87.6139 & 85.87 & 82.63 & (3) 89.6263 \\
\hline $\begin{array}{l}\text { conflict management } \\
\text { (liaise with colleagues) }\end{array}$ & 81.99 & 85.85 & 81.37 & 78.48 & 85.07 \\
\hline networking skills & 80.55 & (3) 91.34 & 75.05 & 70.99 & 83.80 \\
\hline $\begin{array}{l}\text { ability to work in a } \\
\text { (logistics) team }\end{array}$ & 80.36 & 83.64 & 87.11 & 85.36 & 84.48 \\
\hline $\begin{array}{l}\text { ability to follow rules } \\
\text { (comply) }\end{array}$ & 79.14 & 82.11 & 85.51 & (4) 86.0202 & 82.90 \\
\hline presentation skills & 78.38 & nd & 69.59 & $\mathbf{5 7 . 4 7}$ & 74.67 \\
\hline customer orientation & 78.12 & 82.04 & 69.49 & 65.81 & 82.86 \\
\hline
\end{tabular}


research, they are not even among the generally expected competencies. Next in the ranking, with a difference of no less than 1 percentage point, is the systems approach, which the national research listed among the generally expected competencies, as in the case of the purchasing and warehouse managers. Specific competencies in Hungary include technical sense and emotional stamina. Stress tolerance - strongly attached to the latter - was ranked among the moderately expected competencies by the students. As an interesting curiosity, we can point out that independent decision-making ability was only emphasized among the generally expected characteristics by the international research. In the national research (Patóné, 2006), it is the only field in which it did not appear.

The importance of communication skills is increasingly supported by the fact that both Keller's and Patóné's research listed it as a generally expected competency in all fields. The students, however, allocated it 'only' to the sixth place. According to our results, the selection and recruitment ability from Keller's research is best covered in terms of content by organizational skills (first-second place) and independent decision-making ability (fourth place), but other competencies may be useful in this position, for example the systems approach, the ability to control and evaluate, and even the business approach. In our opinion, in this field, the criterion for Keller's (1999) developmental and time management ability is mostly defined by the business approach, for which students are highly likely to have a different view as they ranked it in the penultimate place. Having introduced the expectations in each field, we will now summarize the significant differences in the assessment of each manager competencies.

\section{Labour market expectations by competencies}

Table 6 helps in exploring the correlations, and, in our analysis, we considered the systems approach, the most expected competency in the logistics managers' field, as the baseline. The order of the competencies in the table was thus determined by the order of importance outlined against it. Furthermore - proceeding (by line) by competencies - we marked the highest value in each competency with grey, and the ones that show significant deviation with bold black. To perform the significance test, we applied the Wilcoxon test, in which the initial baseline was always the highest value (grey) of the given competency. The result indicates the manager(s) for which it shows a significant deviation in the assessment of the given competency. With the following table, we focus on analysing these significant differences.

The initial baseline is the system approach - the most important attribute of logistics managers. We can see for this characteristic that - according to the students - there is no other manager field requiring complex vision and the ability to think in systems as much as logistics managers (92.08\%); these are indispensable, since they have to unite all the other fields. The $2.12 \%$ lower value for production managers was already enough to determine a significant deviation. The significance values were .000 for the purchasing manager, .010 for the warehouse manager, .039 for the distribution manager, and .047 for the production manager. According to the students, the above competency is the least expected - with a $9.13 \%$ difference - of purchasing managers, which is clearly visible in Figure 1. Management skills were assessed as most important for the production and the logistics manager. Therefore, there is no significant difference between these two (sig.: .214). However, there is in the case of the three other managers (sig.: .000, .001, .011); furthermore, we see a decrease of more than $8 \%$ for the purchasing manager (sig.: .000). In the assessment of the independent decision-making ability, there is no significant difference between the logistics $(91.23 \%)$, the production $(90.02 \%)$, and the distribution $(88.36 \%)$ manager. In spite of a few hundredths of difference between distribution and purchasing managers (88.28\%), we can see a deviation that is already significant. In the same way, this applies to warehouse managers (85.81\%), for whom independent decision-making ability has already been a fundamental expectation in the earlier national and international research, but - as we mentioned previously - nowadays it is not really expected because of automation. Indeed, of all the managers, they are the ones who need this competency the least, so here the students were correct. It is interesting, however, that, despite of all this, it appears in the fifth place in the competencies of warehouse managers, so it is among the most important ones.

In the assessment of consistency, the same tendency appears for independent decision making (highest for the logistics manager (88.25\%) and deriving the most significance for the purchasing and warehouse managers). The values change the least here; in total, there is a difference of $4.18 \%$ between the highest and the lowest (warehouse manager) value. Organizational skills appear with the highest value $(90.73 \%)$ for the distribution manager, but the difference of more than 3\% compared with the logistics manager is not significant. Hence, organizational skills have, as for the production manager in these three positions, the same importance. However, for the purchasing and warehouse managers, due to the different natures of their tasks, it counts as a less relevant ability, with $84.57-85.06 \%$.

Communication skills are one of the four competencies (with systems approach, negotiation skills, and networking skills) for which, compared with the highest value (here for the purchasing manager: $92.51 \%$ ), there is a significant distinction in the values in all the fields (for the logistics manager, sig.: .001; for the others: .000). The students considered it to be the least significant for the warehouse manager (more than $14.05 \%$ difference, $78.46 \%$ ). This is very surprising, even compared with the results of the national and international research, in which communication skills appeared as a generally expected competency on the manager level. For stress tolerance, as well as for decision-making ability and consistency, the logistics manager is in the 'first' place (86.88\%) and, compared with the purchasing and warehouse managers, shows a significant difference from the lowest value (81.03\%). It is worth mentioning that, to arrive at this distinction, only a 
$1.71 \%$ difference (in the case of the purchasing manager) was enough.

Interestingly, the ability to control and evaluate appears to be the most expected $(89.88 \%)$ for the production manager. This is also the competency, along with the ability to work in a team, that is thought to be similarly important for warehouse managers (distinction within 2\%); therefore, it does not show a significant deviation. The ability to control and evaluate was found to have around $85.8 \%$ (+/- $0.1 \%$ difference) significance, which has already been indicated in the test. We can remark that the students, in the course of class or home teamwork, hardly gave any feedback about their fellow students' work. In our opinion, the reasons for this could be a deficiency of appropriate communication techniques or their inexperience with assertive communication. Hence, it is essential to pay special attention to the development of this field.

The biggest difference lies in the assessment of the business approach. We emphasize the acquisition and proper usage of this aspect as early as in the bachelor's degree, but even more so in the master's degree. As our main aim concerns the training of managers, we assume that students find it essential for every manager. However, the results show the contrary. Here, the distinction is almost 20\%. While the value for the purchasing manager is $86.99 \%$, for the warehouse manager it is $67.38 \%$. Compared with the purchasing manager, the logistics and distribution managers show no significant difference, but the production and warehouse managers do. Negotiation skills appear with the biggest deviation (28.94\%). The highest value, $93.98 \%$, seen for the purchasing manager, is understandable and acceptable. The significant differences can be explained by the large deviation, which was proved for every manager during the test with significance of .000 . The warehouse manager, with $65.04 \%$, has the least need to possess this competency. Collaboration skills are an important criterion for each manager, since a good leader has this attribute. The students confirmed this with a 7\% deviation; the interesting point is that they assigned the highest value to the distribution manager, and a significant difference could be seen only for the warehouse manager. There was only one interesting case - the distribution manager - in which conflict management did not show a significant difference from the purchasing manager $(85.84 \%)$.

Between the most and the least important values, the differences are within $7.36 \%$, which supports the conflict management significance amongst the manager attributes. The networking ability is the attribute with the third-biggest deviation $(20.36 \%)$, which in all cases shows a large difference from the purchasing manager (91.34\%). The distribution manager's - that is, the following one in the row $7.55 \%$ lower value, then the logistics manager's more than $10.5 \%$ difference and the warehouse manager's $20.36 \%$ decrease support this idea, although the exact causes are not clear and could be examined in future research, as in the case of the other significant differences. Teamwork today belongs to almost all positions' fundamental expectations, and, although we have already mentioned it, we would like to highlight that students found it to be the most impor- tant for the production manager (87.11\%), along with the ability to control and evaluate and management skills. The $6.76 \%$ difference also supports the idea that students find it important too, for every manager, in spite of the significant differences for the logistics and purchasing managers. The following is the only ability that is the most expected for the warehouse manager: the ability to follow the rules in this case $(86.02 \%)$ shows a $6.89 \%$ difference from the lowest and a significantly deviating value from that of the logistics manager (79.13\%). However, in the case of the distribution and the purchasing manager, we already consider the not quite $4 \%$ to be a significant deviation.

After the assessment interval of the negotiation skills (28.94\%), the second-largest category is the presentation skills, which students classified as being expected most of all from the logistics (78.37\%) and the distribution manager. The $3.71 \%$ difference between the two does not yet belong to the significantly deviating category; however, the assessments of the production $(69.59 \%)$ and the warehouse manager $(57.47 \%)$ do by all means. Customer orientation is the competency with the fifth-widest scale, which was proved in the course of the test by the difference between the distribution manager $(82.85 \%)$ and the $17.05 \%$ lower-rated warehouse manager.

\section{Evaluation of the results}

In summary, the systems approach and the management skills obtained significantly higher values for the logistics manager, for whom the most important competencies are decision-making ability, consistency, stress management, and presentation skills. In the light of this, we accept hypothesis H1, which was set up to determine the most important criteria for a logistics manager. Furthermore, since, compared with the purchasing manager, there was a significant decrease of values for communication skills, negotiation skills, conflict management, and networking skills, we also accept hypothesis $\mathrm{H} 2$, which was formulated regarding the expectations of a purchasing manager. Therefore, the significantly higher values for negotiation and communication skills in the case of the purchasing manager show the students' awareness of the labour market expectations. For the logistics manager, the ability to control and evaluate and teamwork differed significantly from the values for the production manager, and, in the ability to follow the rules, we can see a significant difference from the warehouse manager's result. Thus, we can say that the scores of the students' research vary between 93.98\% (negotiation skills of the purchasing manager) and $57.47 \%$ (presentation skills of the warehouse manager), which we present in the diagram (Figure 1). The test results were always specialized with regard to the given competency, since it is possible that a $2-3 \%$ difference is already significant in one field, while even a $4-5 \%$ difference does not count as significant in another (e.g. regarding the business approach, the purchasing and distribution managers' $4.71 \%$ difference is quite large, yet the test did not indicate this, while, for the system approach, the $2.11 \%$ difference between logistics and production counts as significant). 
In the assessment of the competencies, six fields showed a difference between the highest and the lowest value between $14.05 \%$ and $28.94 \%$. The biggest difference appeared in the assessment of negotiation skills, close to $30 \%$ in favour of purchasing $(93.98 \%)$ against warehousing $(65.04 \%)$. The presentation skills differed by more than $20.9 \%$ between the logistics manager (78.37\%) and the warehouse manager $(57.47 \%)$. For the networking skills, there was a $20.36 \%$ difference between purchasing (91.34\%) and warehousing (70.98\%). It is also interesting that the business approach, albeit with just over $1 \%$, seems to be more important for a purchasing than for a logistics manager, not to mention the $19.61 \%$ lower value for the warehouse manager. Regarding customer orientation, this difference is $17.05 \%$ between the distribution and the warehouse manager, in favour of the former. Communication skills are at the end of the row among the outstanding values, with a $14.05 \%$ difference between the purchasing and the warehouse manager. Therefore, we can say that, according to the students, in the case of the warehouse manager, except for the ability to work in a team and the ability to control and evaluate, the competencies are significantly less expected. Furthermore, we can remark that the ability to follow the rules was the only one with the highest assessment for the warehouse manager.

Based on the results, it is apparent that the most and least important competencies for a logistics manager are the system approach (92.08\%) and customer orientation (78.11\%). For a purchasing manager, negotiation skills $(93.98 \%)$ and customer orientation $(82.04 \%)$ are the two extremes. For a production manager, the most important is management skills $(92.38 \%)$, whilst customer orientation has $69.48 \%$ importance. The biggest deviation between the most and the least expected competencies appears for the warehouse manager, specifically in the case of management skills (89.45\%) and presentation skills (57.47\%). In the case of the distribution manager, these extreme values are shown by management skills $(90.73 \%)$ and presentation skills $(74.66 \%)$.

\section{Conclusion}

The main motivation of our research was to raise awareness of the competencies required for employment in the supply chain field - aided by contrasting the latest (ESCO, 2020) and the former international research (Keller, 1999) with the results of our research. Through this comparison, those skills and abilities that have to be developed to help students' gain employment and prepare to meet the labour market expectations were emphasized.

We made some suggestions regarding their preparation and utilization of the results. Our results reflect students' evaluation of the competencies required in the fields of the supply chain. This information can be implemented in several ways in the course of training. 1) With the involvement of students: informing students of the results of the research (confrontation), then providing an opportunity for them to offer their opinions. Students would have the possibility individually but also in groups to make development suggestions (educational methodology, the promotion of raising awareness, and the collecting and sharing of professional experience). These suggestions would be evaluated by professors and company managers (in the SCM field) both individually and jointly, and the best ones could be implemented in the curriculum. 2) With the involvement of professors: the knowledge of the results, on the one hand, can help them in choosing the competency-developing methods to be applied in classes, which could increase the effectiveness of the training; on the other hand, it could help to adjust the students' ideas to the market expectations, facilitating the establishment of consistency between the parties. In our opinion, it is important to inform students about the aim of each applied method and its role in achieving practical effectiveness. The methodological support of the professors would be ongoing in the meantime. 3) With the involvement of dual partners and other involved business managers: If employers know the students' perceptions, then, on the one hand, with the help of lectures, they could broaden the minds of students regarding the expected requirements, and, on the other hand, with targeted training and mentoring programmes, they could prepare for the reception of freshly graduated students.

The investigation pointed out numerous differences and accordance between the expected and the assumed competencies. These were supported by the accepted hypotheses, and the extreme assessments were discussed in detail when introducing the results. For instance, presentation skills, according to the students, are the least important for the warehouse manager, while, according to ESCO, they appear here and for the distribution manager as an expectation.

Consequently, there are fields and competencies for which students have to be made aware of the importance and assessment and which have to be developed for them to become marketable employees. The competencies published by ESCO (2020), containing the market expectations of the supply chain, surpass in detail the lists of employer expectations available so far, which we can subordinate to the competencies that we used as umbrella terms, so the labour market expectations used by ESCO regarding purchasing, production, warehouse, distribution, and logistics managers can be classified into the 17 competency groups that we examined. These groups contain several operations/activities that can be developed to help students to become successful in the labour market. To achieve this, it also helps to distinguish the ESCO-listed competencies according to their specific or generic nature (marked in Annex 4) since, during training, there is a greater possibility to develop the 'generic' competencies - which are not profession specific and can be expected of every manager - while the specific attributes come into view and can be developed when already occupying the given position.

There are limitations to our paper. Unfortunately, since the labour market expectations are swiftly changing and percentile results indicating employers' opinion are not available, there is no possibility of setting up a ranking like that in the case of students. Thus, the next step 
would be to question employers and set up a new database in accordance with the market needs, taking into consideration each level of national and international education and the levels of the positions. Most of the examined competencies are such skills and abilities that can be said to be generally expected of managers; therefore, in secondary and higher education, more attention should be paid to the problems of educational methodology as, with clarification, soft skills - which are becoming more important can be developed more effectively.

\section{References}

Athey, T., \& Orth, M. (1999). Emerging competency methods for the future. Human Resource Management, 38(3), 215-225.

https://doi.org/10.1002/(SICI)1099-050X(199923)38:3<215::AID-HRM4>3.0.C0;2-W

Baartman, L. K. J., \& De Bruijn, E. (2011). Integrating knowledge, skills and attitudes: Conceptualising learning processes towards vocational competence. Educational Research Review, 6(2), 125-134. https://doi.org/10.1016/j.edurev.2011.03.001

Boyatzis, R. E. (1982). The competent manager: A model for effect performance. New York, NY: John Wiley.

Boyatzis, R. E. (2008). Competencies in the 21st century. Journal of Management Development, 27(1), 5-12. https://doi.org/10.1108/02621710810840730

Cedefop. (2014). Terminology of European education and training policy. Luxembourg: Publications Office of the European Union. https:// doi.org/10.2801/15877

Chikán, A. (2017). Vállalatgazdaságtan. Budapest, Magyarország: Budapesti Corvinus Egyetem.

Council of the European Union. (2018). Council Recommendation of 22 May 2018 on key competences for lifelong learning. Official Journal of the European Union. https:// eur-lex.europa.eu/legal-content/EN/TXT/ PDF/?uri=CELEX:32018H0604(01)\&rid=7

Demeter, K., Gelei A., Jenei I., \& Nagy J. (2009). Tevékenységmenedzsment. Budapest, Magyarország: Aula Kiadó Kft.

Derwik, P., \& Hellström, D. (2017). Competence in supply chain management: A systematic review. Supply Chain Management: An International Journal, 22(2), 200-218. https://doi.org/10.1108/ SCM-09-2016-0324

Derwik, P., Hellström, D., \& Karlsson, S. (2016). Manager competences in logistics and supply chain practice. Journal of Business Research, 69(11), 4820-4825. https://doi.org/10.1016/j.jbusres.2016.04.037

Employment and Social Development Canada (ESDC). (n.d.). Skills and competencies taxonomy. Retrieved from https://noc.esdc.gc.ca/SkillsTaxonomy/SkillsTaxonomyWelcome/f5ec9457d5a540eeb4529c2698acb19a

ESCO. (2019). Handbook (p. 19). Retrieved from https:// ec.europa.eu/esco/portal/document/hu/0a89839c098d-4e34-846c-54cbd5684d24

ESCO (2020). Competence, skills. Retrieved from https:// ec.europa.eu/esco/portal/escopedia/Competence
ESCO (2020a). ESCO - Skills/competences. Retrieved from https://ec.europa.eu/esco/portal/skill

ESCO (2020b). European skills/competences, qualifications and occupations (ESCO). Retrieved from https:// ec.europa.eu/social/main.jsp?catId=1326\&langId=en

European Parliament and Council of the European Union. (2006). Recommendation of the European Parliament and of the Council of 18 December 2006 on key competences for lifelong learning (2006/962/EC). Official Journal of the European Union. Retrieved from https://eur-lex.europa.eu/LexUriServ/LexUriServ. do?uri=CELEX:32006H0962:EN:HTML

Fabulya, E., Nagy, P., \& Tiszolczi, P. (2017). Kompetencia kézikönyv. Kecskemét: Bács-Kiskun Megyei Kereskedelmi és Iparkamara.

Falus, I. (2010). Javaslat az OKKR szintjeire és szintleirásaira (Vitaindító) [Kézirat]. Retrieved from http:// www.ofi.hu/sites/default/files/ofipast/2010/01/javaslat_ falus_1_21_v3.pdf

Falus, I., Tót, É., Derényi, A., Radó, P., Mártonfi, G., \& Farkas, J. (2009). Kompetencia, tanulási eredmények, képesitési keretrendszerek: Támpontok az Európai Uniós képzési politika új fogalmainak és törekvéseinek megértéséhez a nemzetközi szakirodalom alapján. Budapest: Tempus Közalapítvány.

Flöthmann, C., \& Hoberg, K. (2017). Career patterns of supply chain executives: An optimal matching analysis. Journal of Business Logistics, 38(1), 35-54. https://doi.org/10.1111/jbl.12150 letöltve: 2019.05.10

Gibson, B., Gibson, M., \& Rutner, S. (1998). Careers in logistics. Oak Brook, IL: Council of Logistics Management.

Hoberg, K., Alicke, K., Flöthmann, C., \& Lundin, J. (2014). The DNA of supply chain executives. Supply Chain Management Review, 18(6), 36.

Keller, K. (Ed.) (1999). The growth and development of logistics personnel. Oak Brook, IL: Council of Logistics Management.

Kovács, Z., \& Pató, P. (2014). Job and competency requirements in supply chains. Procedia Social and Behavioral Sciences, 109, 83-91. https://www.researchgate. net/publication/259996033_Jobs_and_Competency Requirements_in_Supply_Chains

KSH. (2020a). Üres álláshelyek száma és aránya. Retrieved from https://www.ksh.hu/docs/hun/xstadat/ xstadat_evkozi/e_qli027a.html

KSH. (2020b). Üres álláshelyek száma és aránya. Retrieved from https://www.ksh.hu/docs/hun/xstadat/ xstadat_evkozi/e_qli027b.html

Lutz, H., \& Birou, L. (2013). Logistics education: A look at the current state of the art and science. Supply Chain Management: An International Journal, 18(4), 455467. https://doi.org/10.1108/SCM-08-2012-0269

Male, S. A., Bush, M. B., \& Chapman, E. S. (2011). An Australian study of generic competencies required by engineers. European Journal of Engineering Education, 36(2), 151-163. https://doi.org/10.1080/03043797.2011.569703 
Mihalkovné Szakács, K. (2014). Vállalkozási ismeretek oktatása vs. vállalkozói kompetenciák fejlesztése. Vezetéstudomány, 45(10), 49-57.

Munkácsi, A. (2019). Az ellátási lánc egyes területein elvárt kompetenciák a logisztikát tanulók szemszögéből. In Modern Gazdaság, Okos Fejlödés Nemzetközi Tudományos Konferencia. Sopron, 7 November 2019, Konferenciakötet (pp. 215-236). Sopron: Soproni Egyetem Kiadó.

Munkácsi, A., \& Demeter, K. (2019). Logisztikai kompetenciák és fejlesztési lehetőségük az oktatásban. Vezetéstudomány, 50(7-8). https://doi.org/10.14267/ VEZ TUD.2019.07.05

Murphy, P. R., \& Poist, Jr., R. F. (1991). Skill requirements of senior level logisticians: Practitioner perspectives. International Journal of Physical Distribution \& Logistics Management, 21(3), 3-14. https://doi. org/10.1108/09600039110004025

Myers, M. B., Griffith, D. A., Daugherty, P. J., \& Lusch, R. F. (2004). Maximizing the human capital equation in logistics: Education, experience, and skills. Journal of Business Logistics, 25(1), 211-232.

Pató Gáborné Szücs B. (Patóné, 2006). Kompetenciák, feladatok logisztikai rendszerekben (Competences, tasks in logistics systems) (Doktori (PhD) értekezés). Pannon Egyetem, Pécs, Magyarország.

Pató, B. S. G., Kovács, K., \& Abonyi, J. (2021). A negyedik ipari forradalom hatása a kompetenciacserélődésre. Vezetéstudomány, 52(1), 56-70. https://doi.org/10.14267/VEZTUD.2021.1.05

Pató, B. S. G., Kovács, Z., \& Pató, G. (2006). Competencies: Required and non-required. Studia Universitatis
Babes-Bolyai, Oeconomica, 1(1), 123-133.

Rychen, D. S. (2004). An overarching conceptual framework for assessing key competences in an international context - Lessons from an interdisciplinary and policy-oriented approach. In Descy, P. \& Tessaring, M. (Eds.), The foundations of evaluation and impact research. Third report on vocational training research in Europe: background report (pp. 315-330). Luxembourg: Office for Official Publications of the European Communities, https://www.cedefop.europa.eu/files/ BgR1_Rychen.pdf

Sauber, M. H., McSurely, H. B., \& Rao Tummala, V. M. (2008). Developing supply chain management program: A competency model. Quality Assurance in Education, 16(4), 375-391.

https://doi.org/10.1108/09684880810906517

Spencer, L. M., \& Spencer, S. M. (1993). Competence at Work: A Model for Superior Performance. New York, NY: John Wiley. In F. Delamare Le Deist \& J. Winterton (2005). What is competence? Human Resource Development International, 8(1), 27-46. https://doi.org/10.1080/1367886042000338227

Thai, V. V., Cahoon, S., \& Tran, H. T. (2011). Skill requirements for logistics professionals: Findings and implications. Asia Pacific Journal of Marketing and Logistics, 23(4), 553-574. https://doi. org/10.1108/13555851111165084

Van Hoek, R. I. (2001). Logistics education: Achieving market and research driven skill development. International Journal of Physical Distribution \& Logistics Management, 31(7/8), 505-519. https://doi.org/10.1108/EUM0000000005906 


\section{Annex}

1. Expected specific competencies in certain areas of supply chains based on Keller (1999)

\begin{tabular}{|c|c|c|c|c|}
\hline $\begin{array}{l}\text { Expected } \\
\text { competencies in } \\
\text { purchasing }\end{array}$ & $\begin{array}{c}\text { Expected } \\
\text { competencies in } \\
\text { warehousing }\end{array}$ & $\begin{array}{c}\text { Expected } \\
\text { competencies in } \\
\text { production }\end{array}$ & $\begin{array}{c}\text { Expected } \\
\text { competencies } \\
\text { in distribution }\end{array}$ & $\begin{array}{l}\text { Expected comprehensive } \\
\text { competencies in the } \\
\text { logistics field within the } \\
\text { company }\end{array}$ \\
\hline $\begin{array}{l}\text { use of communication } \\
\text { techniques }\end{array}$ & $\begin{array}{l}\text { Warehouse } \\
\text { inspector: }\end{array}$ & $\begin{array}{l}\text { decision-making } \\
\text { ability }\end{array}$ & control ability & Logistics managers: \\
\hline $\begin{array}{l}\text { use of conflict, and } \\
\text { stress management } \\
\text { techniques }\end{array}$ & $\begin{array}{l}\text { ability to train } \\
\text { people }\end{array}$ & ability to control & $\begin{array}{c}\text { developmental } \\
\text { ability }\end{array}$ & $\begin{array}{c}\text { ability to build, maintain, } \\
\text { and develop a logistics } \\
\text { organization }\end{array}$ \\
\hline \multirow[t]{11}{*}{$\begin{array}{l}\text { ability to conduct } \\
\text { meetings }\end{array}$} & $\begin{array}{l}\text { ability to control } \\
\text { (ability to evaluate } \\
\text { performance) }\end{array}$ & developmental ability & $\begin{array}{c}\text { effective } \\
\text { decision- } \\
\text { making ability }\end{array}$ & $\begin{array}{l}\text { selecting, developing, } \\
\text { motivating, and } \\
\text { controlling the right } \\
\text { people }\end{array}$ \\
\hline & communication skills & $\begin{array}{l}\text { time management } \\
\text { ability }\end{array}$ & $\begin{array}{c}\text { time } \\
\text { management } \\
\text { ability }\end{array}$ & team-building ability \\
\hline & ability to motivate & $\begin{array}{c}\text { excellent } \\
\text { communication skills }\end{array}$ & $\begin{array}{c}\text { selection, and } \\
\text { recruitment } \\
\text { ability } \\
\end{array}$ & $\begin{array}{l}\text { communication, } \\
\text { presentation skills }\end{array}$ \\
\hline & stress management & ability to motivate & $\begin{array}{c}\text { communication } \\
\text { skills }\end{array}$ & $\begin{array}{l}\text { decision-making methods, } \\
\text { and techniques }\end{array}$ \\
\hline & $\begin{array}{l}\text { time management } \\
\text { ability }\end{array}$ & & $\begin{array}{c}\text { ability to teach } \\
\text { others }\end{array}$ & Supply Chain Manager: \\
\hline & $\begin{array}{c}\text { user-level } \\
\text { management of } \\
\text { technical devices }\end{array}$ & & $\begin{array}{l}\text { leadership } \\
\text { skills }\end{array}$ & comprehensive vision \\
\hline & organizational skills & & & $\begin{array}{c}\text { stress, and conflict } \\
\text { management }\end{array}$ \\
\hline & $\begin{array}{l}\text { Warehouse manager } \\
\text { in addition to these: }\end{array}$ & & & project management skills \\
\hline & $\begin{array}{l}\text { decision-making } \\
\text { ability }\end{array}$ & & & $\begin{array}{l}\text { communication, } \\
\text { presentation skills }\end{array}$ \\
\hline & presentation skills & & & organizational skills \\
\hline & & & & $\begin{array}{l}\text { effective decision-making } \\
\text { ability }\end{array}$ \\
\hline
\end{tabular}

Source: Munkácsi \& Demeter (2019); own compilation (2020)

\section{Expected specific competencies in certain areas of} supply chains based on Patóné (2006)

\begin{tabular}{|c|c|c|c|}
\hline $\begin{array}{c}\text { Expected competencies } \\
\text { in purchasing }\end{array}$ & $\begin{array}{c}\text { Expected competencies } \\
\text { in warehousing }\end{array}$ & $\begin{array}{c}\text { Expected } \\
\text { competencies in the } \\
\text { field of transport and } \\
\text { material handling }\end{array}$ & $\begin{array}{c}\text { Competencies related } \\
\text { to comprehensive } \\
\text { logistics within the } \\
\text { company }\end{array}$ \\
\hline comprehensive vision & endurance, adaptability & emotional stamina & \begin{tabular}{|l} 
information \\
management, \\
organizational \\
awareness
\end{tabular} \\
\hline team-building ability & $\begin{array}{l}\text { well-groomed, good- } \\
\text { looking, reviewing ability }\end{array}$ & technical sense & initiative skills \\
\hline ability to control & extroversion, attention & & creativity \\
\hline responsibility & conflict management & & logical thinking \\
\hline expressiveness & consistency & & confident attitude \\
\hline risk-taking skill & directness & & quality awareness \\
\hline complex mindset & solvency, methodicality & & being motivated \\
\hline negotiation skill & systematism & & $\begin{array}{l}\text { work organization } \\
\text { ability }\end{array}$ \\
\hline company-level mindset & professional aptitude & & independent work \\
\hline customer orientation & courtesy & & flexibility \\
\hline
\end{tabular}

Source: Munkácsi \& Demeter (2019); own compilation
3. Categories and grouping of the 23 personal competencies in the EU's research programme (2006)

\begin{tabular}{|c|c|c|}
\hline Key competences & Work competences & $\begin{array}{c}\text { Management } \\
\text { competences }\end{array}$ \\
\hline communication & flexibility & leadership \\
\hline quantification skills & creativity & ability to motivate others \\
\hline teamwork & $\begin{array}{c}\text { early independent } \\
\text { decision making }\end{array}$ & $\begin{array}{c}\text { the ability to learn from } \\
\text { mistakes }\end{array}$ \\
\hline problem-solving ability & $\begin{array}{c}\text { knowledge of foreign } \\
\text { language(s) }\end{array}$ & $\begin{array}{c}\text { ability to handl contacts, } \\
\text { and build new contacts }\end{array}$ \\
\hline $\begin{array}{c}\text { ability to learn, and } \\
\text { develop performance }\end{array}$ & confidence & ability to influence others \\
\hline & critical approach & $\begin{array}{c}\text { ability of decision } \\
\text { making }\end{array}$ \\
\hline & $\begin{array}{c}\text { obility to explore new } \\
\text { opportunities }\end{array}$ & $\begin{array}{c}\text { ability to focus on the } \\
\text { results, and the execution } \\
\text { of processes }\end{array}$ \\
\hline & responsibility & ability to build strategies \\
\hline & capacity to act & ethical approach \\
\hline
\end{tabular}

Source: Fabulya et al., (2017); own compilation 
STUDIES AND ARTICLES

4. ESCO's fundamentally and optionally expected competencies in certain fields of logistics marked as 'Generic (Gen.)' and 'Specific (Spec.)' competencies

\begin{tabular}{|c|c|c|c|c|c|c|c|c|c|}
\hline \begin{tabular}{|l} 
Gen. \\
Spec.
\end{tabular} & $\begin{array}{l}\text { Essential skills and } \\
\text { competences logistics and } \\
\text { distribution manager }\end{array}$ & $\begin{array}{l}\text { Gen./ } \\
\text { Spec. }\end{array}$ & \begin{tabular}{|l|} 
Essential skills and \\
competences purchasing \\
manager
\end{tabular} & $\begin{array}{l}\text { Gen.// } \\
\text { Spec. }\end{array}$ & $\begin{array}{l}\text { Essential skills and } \\
\text { competences warehouse } \\
\text { manager }\end{array}$ & $\begin{array}{l}\text { Gen. } \\
\text { Spec }\end{array}$ & $\begin{array}{l}\text { Essential skills and } \\
\text { competences industrial } \\
\text { production manager }\end{array}$ & $\begin{array}{l}\text { Gen./ } \\
\text { Spec. }\end{array}$ & $\begin{array}{l}\text { Essential skills and } \\
\text { competences distribution } \\
\text { manager }\end{array}$ \\
\hline $\mathrm{s}$ & $\begin{array}{l}\text { analyse relation between supply } \\
\text { chain improvement and profit }\end{array}$ & $\mathrm{s}$ & analyse logistic changes & G & apply safety management & G & $\begin{array}{l}\text { adhere to organisational } \\
\text { guidelines }\end{array}$ & G & $\begin{array}{l}\text { adhere to organisational } \\
\text { guidelines }\end{array}$ \\
\hline $\mathrm{s}$ & analyse supply chain strategies & $\mathrm{s}$ & $\begin{array}{l}\begin{array}{l}\text { analyse supply chain } \\
\text { strategies }\end{array} \\
\end{array}$ & G & build business relationships & $\mathrm{s}$ & adjust production schedule & $\mathrm{s}$ & $\begin{array}{l}\text { carry out inventory control } \\
\text { accuracy }\end{array}$ \\
\hline $\mathrm{s}$ & analyse supply chain trends & $\mathrm{s}$ & $\begin{array}{l}\begin{array}{l}\text { analyse supply chain } \\
\text { trends }\end{array} \\
\end{array}$ & G & coach employees & $\mathrm{s}$ & $\begin{array}{l}\text { assess impact of industrial } \\
\text { activities }\end{array}$ & G & carry out statistical forecasts \\
\hline $\mathrm{s}$ & $\begin{array}{l}\begin{array}{l}\text { anticipate the overhaul of the } \\
\text { fleet }\end{array} \\
\text {. }\end{array}$ & $\mathrm{s}$ & assess supplier risks & G & $\begin{array}{l}\text { comprehend financial business } \\
\text { terminology }\end{array}$ & $\mathrm{s}$ & check material rescources & $\mathrm{s}$ & $\begin{array}{l}\text { communicate with shipment } \\
\text { forwarders }\end{array}$ \\
\hline $\mathrm{s}$ & $\begin{array}{l}\text { communicate with shipment } \\
\text { forwarders }\end{array}$ & $\mathrm{s}$ & $\begin{array}{l}\text { coordinate purchasing } \\
\text { activities }\end{array}$ & G & $\begin{array}{l}\text { create a work atmosphere of } \\
\text { continuous improvement }\end{array}$ & G & control financial resources & G & create solutions to problems \\
\hline G & comply with checklists & $\mathrm{s}$ & \begin{tabular}{|l|}
$\begin{array}{l}\text { estimate costs of required } \\
\text { supplies }\end{array}$ \\
\end{tabular} & G & create solutions to problems & $\mathrm{s}$ & create manufacturing guidelines & G & $\begin{array}{l}\text { develop financial statistics } \\
\text { reports }\end{array}$ \\
\hline $\mathrm{s}$ & $\begin{array}{l}\text { conduct full-scale emergency } \\
\text { plan exercises }\end{array}$ & G & follow company standards & $\mathrm{s}$ & $\begin{array}{l}\text { ensure efficient utilisation of } \\
\text { warehouse space }\end{array}$ & $\mathrm{s}$ & define quality standards & $\mathrm{s}$ & ensure customs compliance \\
\hline G & $\begin{array}{l}\text { consider economic criteria in } \\
\text { decision making }\end{array}$ & $\mathrm{s}$ & identify suppliers & $\mathrm{s}$ & ensure stock storage safety & G & $\begin{array}{l}\begin{array}{l}\text { liaise with industrial } \\
\text { professionals }\end{array} \\
\end{array}$ & $\mathrm{s}$ & \begin{tabular}{|l|}
$\begin{array}{l}\text { ensure regulatory } \\
\text { compliance concerning } \\
\text { distribution activities }\end{array}$ \\
\end{tabular} \\
\hline $\mathrm{s}$ & control reorder points & G & issue sales invoices & G & $\begin{array}{l}\text { exert a goal-oriented leadership } \\
\text { role towards colleagues }\end{array}$ & G & manage budgets & $\mathrm{s}$ & $\begin{array}{l}\text { forecast distribution } \\
\text { activities }\end{array}$ \\
\hline $\mathrm{s}$ & coordinate dock operations & G & liaise with managers & G & give instructions to staff & $\mathrm{s}$ & manage resources & $\mathrm{s}$ & handle carriers \\
\hline $\mathrm{s}$ & $\begin{array}{l}\text { develop efficiency plans for } \\
\text { logistics operations }\end{array}$ & G & $\begin{array}{l}\text { maintain relationship with } \\
\text { customers }\end{array}$ & $\mathrm{s}$ & $\begin{array}{l}\text { identify software for warehouse } \\
\text { management }\end{array}$ & G & manage staff & G & have computer literacy \\
\hline G & $\begin{array}{l}\text { encourage teams for continuous } \\
\text { improvement }\end{array}$ & $\mathrm{s}$ & \begin{tabular}{|l|} 
maintain relationship with \\
suppliers
\end{tabular} & G & improve business processes & s & manage supplies & G & implement strategic planning \\
\hline G & $\begin{array}{l}\text { ensure continuous preparedness } \\
\text { for audits }\end{array}$ & G & manage budgets & G & maintain financial records & G & meet deadlines & G & manage financial risk \\
\hline G & give instructions to staff & G & manage contracts & $\mathrm{s}$ & $\begin{array}{l}\text { maintain physical condition of } \\
\text { warehouse }\end{array}$ & s & oversee assembly operations & $\mathrm{s}$ & $\begin{array}{l}\text { manage freight payment } \\
\text { methods }\end{array}$ \\
\hline $\mathrm{G}$ & handle stressful situations & $\mathrm{s}$ & manage inventory & $\mathrm{s}$ & maintain stock control systems & $\mathrm{s}$ & $\begin{array}{l}\text { oversee production } \\
\text { requirements }\end{array}$ & G & manage staff \\
\hline G & liaise with colleagues & $\mathrm{s}$ & $\begin{array}{l}\text { negotiate buying } \\
\text { conditions }\end{array}$ & $\mathrm{s}$ & maintain warehouse database & $\mathrm{s}$ & $\begin{array}{l}\text { plan health and safety } \\
\text { procedures }\end{array}$ & $\mathrm{s}$ & minimise shipping cost \\
\hline $\mathrm{s}$ & \begin{tabular}{|l} 
liaise with transportation \\
companies
\end{tabular} & $\mathrm{s}$ & negotiate sales contracts & $\mathrm{s}$ & $\begin{array}{l}\text { manage dispatch software } \\
\text { systems }\end{array}$ & & $\begin{array}{l}\text { Optional skills and } \\
\text { competences industrial } \\
\text { production manager }\end{array}$ & $\mathrm{s}$ & \begin{tabular}{|l|} 
perform financial risk \\
management in international \\
trade
\end{tabular} \\
\hline $\mathrm{s}$ & $\begin{array}{l}\text { manage dispatch software } \\
\text { systems }\end{array}$ & $\mathrm{s}$ & order supplies & $\mathrm{s}$ & manage inventory & s & adapt production levels & G & $\begin{array}{l}\text { perform multiple tasks at the } \\
\text { same time }\end{array}$ \\
\hline G & manage staff & G & strive for company growth & G & manage staff & G & analyse goal progress & G & perform risk analysis \\
\hline $\mathrm{s}$ & $\begin{array}{l}\text { manage the fleet according to } \\
\text { planned operations }\end{array}$ & $\mathrm{s}$ & \begin{tabular}{|l} 
study sales levels of \\
products
\end{tabular} & $\mathrm{s}$ & $\begin{array}{l}\text { manage third-party logistics } \\
\text { providers }\end{array}$ & $\mathrm{s}$ & $\begin{array}{l}\text { analyse production processes } \\
\text { for improvement }\end{array}$ & $\mathrm{s}$ & plan transport operations \\
\hline G & $\begin{array}{l}\text { perform cost accounting } \\
\text { activities }\end{array}$ & & \begin{tabular}{|l|}
$\begin{array}{l}\text { Optional skills and } \\
\text { competences purchasing } \\
\text { manager }\end{array}$ \\
\end{tabular} & $\mathrm{s}$ & manage warehouse operations & $\mathrm{s}$ & analyse supply chain strategies & $\mathrm{s}$ & track shipments \\
\hline G & \begin{tabular}{|l}
$\begin{array}{l}\text { provide operational efficiency } \\
\text { training to employees }\end{array}$ \\
\end{tabular} & G & \begin{tabular}{|l|}
$\begin{array}{l}\text { analyse consumer buying } \\
\text { trends }\end{array}$ \\
\end{tabular} & $\mathrm{s}$ & manage warehouse organisation & $\mathrm{s}$ & assess supplier risks & $\mathrm{s}$ & track shipping sites \\
\hline $\mathrm{s}$ & $\begin{array}{l}\text { solve operational transport } \\
\text { problems }\end{array}$ & s & assess procurement needs & $\mathrm{s}$ & meet productivity targets & $\mathrm{s}$ & $\begin{array}{l}\text { check quality of products on } \\
\text { the production line }\end{array}$ & & \begin{tabular}{|l|}
$\begin{array}{l}\text { Optional skills and } \\
\text { competences distribution } \\
\text { manager }\end{array}$ \\
\end{tabular} \\
\hline \multirow[t]{2}{*}{$\mathrm{s}$} & work in a logistics team & G & attend trade fairs & $\mathrm{s}$ & $\begin{array}{l}\text { monitor security procedures in } \\
\text { warehouse operations }\end{array}$ & $\mathrm{s}$ & check quality of raw materials & G & ensure customer focus \\
\hline & \begin{tabular}{|l|}
$\begin{array}{l}\text { Optional skills and } \\
\text { competences logistics and } \\
\text { distribution manager }\end{array}$ \\
\end{tabular} & $\mathrm{s}$ & \begin{tabular}{|l|} 
calculate purchasing levels \\
of raw materials
\end{tabular} & $\mathrm{s}$ & monitor storage space & $\mathrm{s}$ & $\begin{array}{l}\text { define manufacturing quality } \\
\text { criteria }\end{array}$ & $\mathrm{s}$ & manufacture ingredients \\
\hline $\mathrm{s}$ & \begin{tabular}{|l} 
check dangerous goods \\
transport unit
\end{tabular} & G & $\begin{array}{l}\text { carry out statistical } \\
\text { forecasts }\end{array}$ & $\mathrm{s}$ & $\begin{array}{l}\text { oversee freight-related financial } \\
\text { documentation }\end{array}$ & G & develop business plans & $\mathrm{s}$ & \begin{tabular}{|l|} 
monitor security procedures \\
in warehouse operations
\end{tabular} \\
\hline G & cooperate with colleagues & $\mathrm{s}$ & \begin{tabular}{|l|}
$\begin{array}{l}\text { ensure equipment } \\
\text { availability }\end{array}$ \\
\end{tabular} & $\mathrm{s}$ & $\begin{array}{l}\text { oversee warehouse value-added } \\
\text { activities }\end{array}$ & $\mathrm{s}$ & develop manufacturing policies & $\mathrm{s}$ & monitor stock level \\
\hline $\mathrm{s}$ & $\begin{array}{l}\text { coordinate export transportation } \\
\text { activities }\end{array}$ & s & \begin{tabular}{|l|}
$\begin{array}{l}\text { implement procurement of } \\
\text { innovation }\end{array}$ \\
\end{tabular} & G & $\begin{array}{l}\text { perform cost accounting } \\
\text { activities }\end{array}$ & G & inspect material & $\mathrm{s}$ & $\begin{array}{l}\begin{array}{l}\text { oversee freight-related } \\
\text { financial documentation }\end{array} \\
\end{array}$ \\
\hline $\mathrm{s}$ & $\begin{array}{l}\text { coordinate import transportation } \\
\text { activities }\end{array}$ & $\mathrm{s}$ & $\begin{array}{l}\text { implement sustainable } \\
\text { procurement }\end{array}$ & $\mathrm{s}$ & plan future capacity requirements & $\mathrm{s}$ & schedule production & G & present reports \\
\hline G & have computer literacy & G & \begin{tabular}{|l} 
maintain contract \\
administration
\end{tabular} & $\mathrm{s}$ & plan the dispatching of products & & & $\mathrm{G}$ & speak different languages \\
\hline $\mathrm{s}$ & \begin{tabular}{|l|} 
identify software for warehouse \\
management
\end{tabular} & $\mathrm{s}$ & $\begin{array}{l}\text { manage procurement } \\
\text { planning }\end{array}$ & $\mathrm{s}$ & plan the stocking of products & & & G & think proactively \\
\hline $\mathrm{s}$ & improve rail service delivery & $\mathrm{s}$ & $\begin{array}{l}\text { manage rented goods } \\
\text { returns }\end{array}$ & $\mathrm{s}$ & $\begin{array}{l}\text { provide staff training in } \\
\text { warehouse management }\end{array}$ & & & G & train employees \\
\hline $\mathrm{s}$ & liaise with port users & G & manage staff & G & schedule shifts & & & $\mathrm{s}$ & \begin{tabular}{|l|}
$\begin{array}{l}\text { use a warehouse } \\
\text { management system }\end{array}$ \\
\end{tabular} \\
\hline $\mathrm{s}$ & $\begin{array}{l}\text { oversee warehouse value-added } \\
\text { activities }\end{array}$ & $\mathrm{s}$ & manage supplies & G & train employees & & & & \\
\hline G & show confidence & $\mathrm{s}$ & monitor stock level & $\mathrm{s}$ & $\begin{array}{l}\text { use a warehouse management } \\
\text { system }\end{array}$ & & & & \\
\hline \multirow[t]{15}{*}{ G } & $\begin{array}{l}\begin{array}{l}\text { use different communication } \\
\text { channels }\end{array} \\
\end{array}$ & $\mathrm{s}$ & $\begin{array}{l}\text { perform procurement } \\
\text { market analysis }\end{array}$ & G & $\begin{array}{l}\text { use different communication } \\
\text { channels }\end{array}$ & & & & \\
\hline & & $\mathrm{s}$ & $\begin{array}{l}\begin{array}{l}\text { promote sustainable } \\
\text { management }\end{array} \\
\end{array}$ & $\mathrm{s}$ & work in a logistics team & & & & \\
\hline & & G & recruit employees & & \begin{tabular}{|l|} 
Optional skills and \\
competences warehouse \\
manager
\end{tabular} & & & & \\
\hline & & G & track price trends & G & act reliably & & & & \\
\hline & & G & train employees & G & $\begin{array}{l}\begin{array}{l}\text { analyse work-related written } \\
\text { reports }\end{array} \\
\end{array}$ & & & & \\
\hline & & $\mathrm{s}$ & use e-procurement & $\mathrm{s}$ & $\begin{array}{l}\begin{array}{l}\text { carry out storage risk } \\
\text { management }\end{array} \\
\end{array}$ & & & & \\
\hline & & & & $\mathrm{s}$ & \begin{tabular}{|l|} 
ensure safety conditions in storage \\
rooms
\end{tabular} & & & & \\
\hline & & & & G & have computer literacy & & & & \\
\hline & & & & G & $\begin{array}{l}\text { maintain updated professional } \\
\text { knowledge }\end{array}$ & & & & \\
\hline & & & & G & manage budgets & & & & \\
\hline & & & & G & $\begin{array}{l}\text { perform services in a flexible } \\
\text { manner }\end{array}$ & & & & \\
\hline & & & & G & present reports & & & & \\
\hline & & & & $\bar{G}$ & show confidence & & & & \\
\hline & & & & G & $\begin{array}{l}\text { supervise the work of staff on } \\
\text { different shifts }\end{array}$ & & & & \\
\hline & & & & $\mathrm{G}$ & use logical reasoning & & & & \\
\hline
\end{tabular}

